\section{Journal of Global \\ Management Sciences}

Vol. 3, $\mathbf{N}^{\circ} 2,2020$

\title{
The asparagus production chain of the Ica valley, 2019: A general analysis with small asparagus producers [La cadena productiva del espárrago del valle de Ica, 2019: un análisis general con los pequeños Productores de esparrago]
}

\author{
Alejandro Alfredo Quispe Mayuri, Leonidas Alejandro Maldonado Bendezú \\ lka17@hotmail.com
}

Received: 26 August 2020; Accepted: 15 September 2020; Published: 30 September 2020

\begin{abstract}
Resumen
En el presente artículo se estableció como propósito tener una visión de algunos aspectos de la cadena productiva del esparrago en el valle de Ica, y con ello tener una apreciación más clara de las actividades que se desarrollan los agentes de distribución logística, la importancia de los fondos de financiamiento, y además la planeación de la demanda. Un factor importante en las transformaciones en las instituciones agropecuarias parte de la necesidad de sus directivos de analizar e identificar el enorme potencial de las cadenas de producción y del desarrollo de la planificación estratégica para obtener un desarrollo sostenible. El estudio se orientó en establecer el marco teórico de referencia y de esta manera entender la articulación productiva. Se concluye que de las cadenas productivas en el esparrago constituyen una alternativa estratégica que se orienta a la búsqueda de diversas líneas de acción que posibiliten a las organizaciones obtener mejores resultados comerciales, posicionarse mejor en los mercados, alcanzar niveles de productividad, y con ello lograr el funcionamiento eficiente de sus procesos internos. Además, se establece que en la dimensión Agente distribución logística, se consideraron las actividades de atención de pedidos, manipulación de los materiales, en el uso de la variedad de embalajes, y el transporte de los productos se lograron un nivel eficiente de desempeño de estas actividades.
\end{abstract}

Palabras clave: Cadena productiva, espárrago, competitividad comercial

\begin{abstract}
The purpose of this article was to have a vision of some aspects of the asparagus production chain in the Ica valley, and thus have a clearer appreciation of the activities carried out by logistics distribution agents, the importance of financing funds, and also demand planning. An important factor in the transformations at agricultural institutions stems from the need for their managers to analyze and identify the enormous potential of production chains and development of strategic planning to obtain sustainable development. The study was oriented in establishing the theoretical frame of reference and in this way to understand the productive articulation.

It is concluded that the productive chains in asparagus constitute a strategic alternative that is oriented towards the search for different lines of action that enable organizations to obtain better commercial results, better position themselves in the markets, reach productivity levels, and thereby achieve the efficient operation of its internal processes. In addition, it is established that in the logistics distribution agent dimension, an efficient level of performance will be achieved in order fulfillment activities, material handling, the use of a variety of packaging, and the transport of products of these activities.
\end{abstract}

Keywords: Productive chain, asparagus, commercial competitiveness. 
Vol. 3, $\mathbf{N}^{\circ}$ 2, 2020

\section{GMS \\ Journal of Global Management Sciences}

Copyright (C 2020, CINCADER.

ISSN 2663-0753

DOI: https://doi.org/10.32829/gms.v3i2.176

\section{Introduction}

The development of productive chains emerges as an important option to achieve collective efficiency, but its development requires coherent and solid state policies, development of competitive advantages and a thorough understanding of such a changing, unpredictable and dynamic environment.

Agribusiness is an extremely complex activity, and in it agricultural and industrial activity is appreciated, so it is necessary to achieve technological developments, capital injections, more efficient and technologically sophisticated distribution and marketing systems that are necessary to reach the final consumer, which is who accepts or rejects the products and defines the degrees of internal transformation (Romero, 2001).

The productive chain is conceptualized as: "the sequential set of actors that participate in successive transactions for the generation of a good or service, including the primary sector to the final consumer and the services provided throughout the chain" (Lazzarini et al, 2001)

Kaplinsky (2000) defines the production chain as: "an analysis tool that allows identifying the main critical and potential development points, and then defining and promoting strategies focused on the actors involved."

The clusters represent a unit of analysis of intermediate competition between the company and the industry, which have an intangible importance in the business environment of a locality, beyond the collection of taxes, service costs or salaries (Porter, 2000).

It is taken into consideration that the critical aspects facing the asparagus agro-productive chain led to the establishment of some cooperation mechanisms promoted by some state organizations and private companies. This has allowed the uniting of both producers and exporters with public institutions, developing research, technology transfers, market studies, commercial promotion, health and quality (O'Brien and Díaz, 2004).

Having made the diagnosis of the problem of the small producers of Francisco Alvitez and Reque, it was determined that they face various problems that have not allowed them to increase productivity and as a result achieve better levels of competitiveness; Among these factors we have: a) Low associativity levels, b) Deficient community and business management capacity, c) Lack of technical capacities in the agronomic management of the crop, d) Deficient technological level in the management of water resources and d) difficulties in the articulation with the market (Coronel, 2018).

The agricultural production chain of asparagus in the Ica valley faces some difficulties that are related to a set of factors that are associated with the commercial aspect as a result of export orientation, and they include various topics that are related to supply, the supply of product, of raw materials, from the places of production to different places of transformation and final consumption, also involves the system of road networks for communication, the different ways of mobilizing and the transformation factories and the way of marketing. This process is directed by different people and state and private institutions, all of them work under different rules of national and international influence.

This study will make it possible to have a vision of the asparagus production chains, which, in most cases, need financial support and technical support, in addition they require developing some business management skills and being able to determine the supply and demand of their product. It is important to identify, evaluate and develop new opportunities, enable access to markets, developing more efficient organizations that are capable of promoting innovation in new 


\section{GMS \\ Journal of Global Management Sciences}

Vol. 3, $\mathrm{N}^{\circ}$ 2, 2020
Copyright @ 2020 , CINCADER.

ISSN 2663-0753

DOI: https://doi.org/10.32829/gms.v3i2.176

technologies and access to new markets, fostering growth and business development of these production units and the economic development of the city of Ica.

The main markets for Peruvian asparagus are shown below

Table 1. Main markets for Peruvian asparagus

\begin{tabular}{cccc}
\hline Market & $\%$ Var & $\%$ Part. & $\begin{array}{c}\text { FOB-19 } \\
\text { (miles US } \$ \text { ) }\end{array}$ \\
\hline United States & $19-18$ & 19 & $251,853.23$ \\
United Kingdom & $9 \%$ & $63 \%$ & $38,779.69$ \\
Netherlands & $-9 \%$ & $10 \%$ & $38,472.29$ \\
Spain & $-8 \%$ & $10 \%$ & $31,768.74$ \\
Brazil & $8 \%$ & $8 \%$ & $4,685.33$ \\
Canada & $-2 \%$ & $1 \%$ & $4,546.63$ \\
Belgium & $158 \%$ & $1 \%$ & $4,453.45$ \\
France & $29 \%$ & $1 \%$ & $2,593.31$ \\
Germany & $-5 \%$ & $1 \%$ & $2,549.16$ \\
Other countries (32) & $-17 \%$ & $1 \%$ & $20,174.32$ \\
\hline
\end{tabular}

Source: SUNAT.

\section{Materials and methods}

The research carried out is of the Applied type, it is characterized because it seeks the application or use of the acquired knowledge, at the same time that others are acquired, after implementing and systematizing the research-based practice (Murillo, 2008). The level of study was descriptive, because it is intended to use the knowledge and the different experiences that exist in this sector (Zorrilla, 2007). The inductive method was also used because we start from particular situations to later develop generalizations. The population that was considered for the study were the small asparagus producers of the Ica Valley in 2019. There are approximately 305. (Pineda et al., 1994: 108). Using for this the type of simple random sampling and it was determined that the sample under study is 179 sample elements, of which 143 are men and 36 women. The survey and its instrument the questionnaire were used to collect important information about the most relevant characteristics of the small asparagus producers of the Ica Valley. The questionnaire was structured considering the following dimensions: i). Agents of logistics distribution, where four items were considered, ii). Financing funds, where four items were considered, and lii). Demand analysis, where four items were considered.

\section{Results}

In the development of the investigation the following results were obtained. 


\section{GMS \\ Journal of Global Management Sciences}

Vol. 3, $\mathrm{N}^{\circ}$ 2, 2020
Copyright (C) 2020, CINCADER.

ISSN 2663-0753

DOI: https://doi.org/10.32829/gms.v3i2.176

\section{CINCADER}

Centre of Research and Training for

Regional Development

Online at www.journals.cincader.org

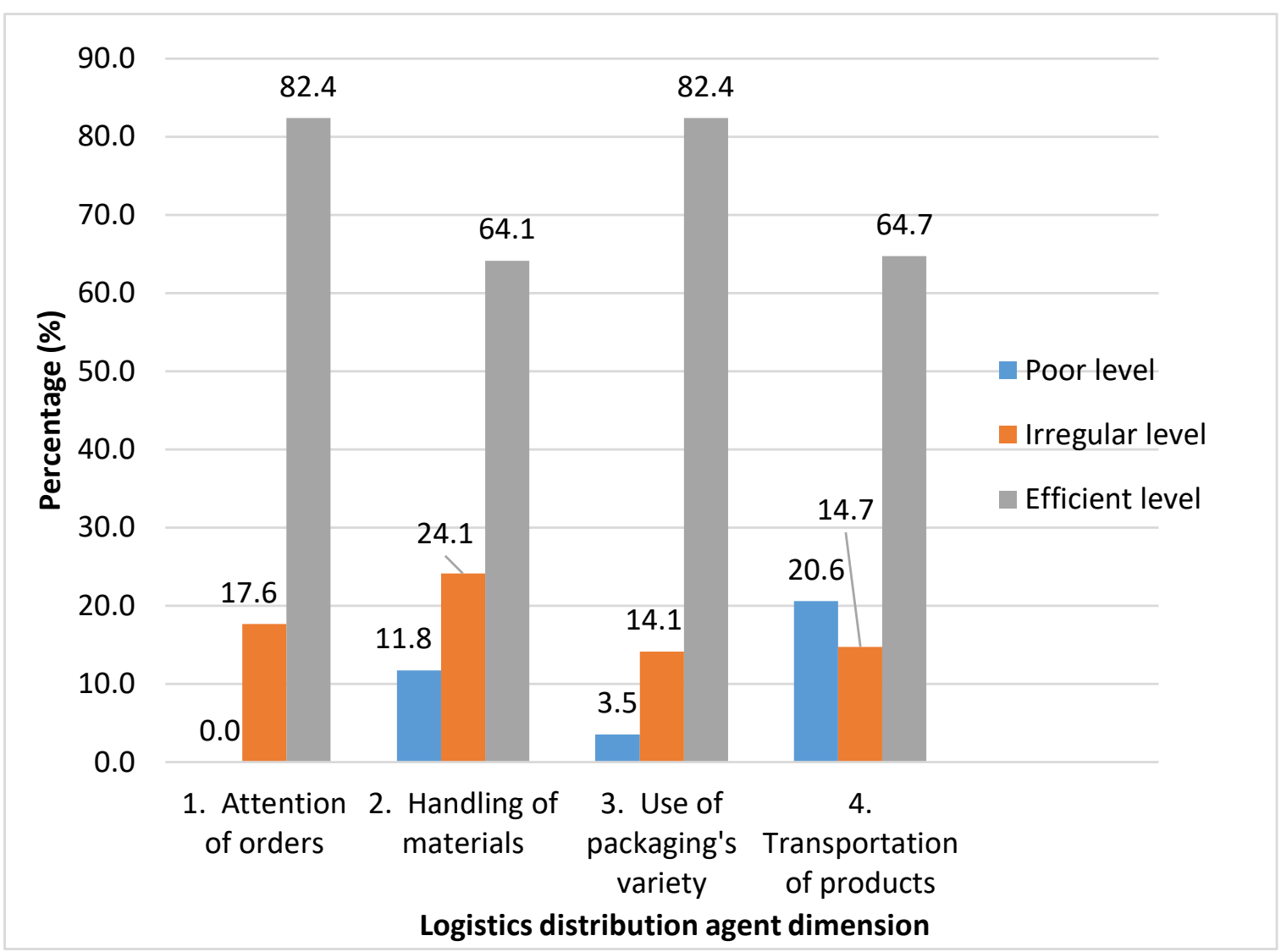

Figure 1. Logistics distribution agents

The Logistics Distribution Agent dimension. The activities of order fulfillment, material handling, use of a variety of packaging, and the transport of products were taken into consideration. Taking into account the order attention indicator, the following results were achieved: $82.4 \%$ of those surveyed stated that an efficient level was reached, in this indicator, $17.6 \%$ stated that they achieved an irregular level. Taking into consideration the material handling indicator, the following results were obtained: $64.1 \%$ of those surveyed stated that an efficient level was reached, in this indicator, $24.1 \%$ expressed that it achieved an irregular level and $11.8 \%$ said that a poor level was obtained. Taking into account the indicator uses of the variety of packaging, the following results were obtained: $82.4 \%$ of the respondents stated that an efficient level was reached, in this indicator, $14.1 \%$ expressed that it achieved an irregular level and $3.5 \%$ said a poor level was obtained. Taking into consideration the product transport indicator, the following results were obtained: $64.7 \%$ of those surveyed stated that an efficient level was reached, in this indicator, $14.7 \%$ stated that it achieved an irregular level and $20.6 \%$ said that it was got a poor level. 


\section{GMS \\ Journal of Global Management Sciences}

Vol. 3, $\mathrm{N}^{\circ}$ 2, 2020
Copyright (C) 2020, CINCADER.

ISSN 2663-0753

DOI: https://doi.org/10.32829/gms.v3i2.176

\section{CINCADER}

Centre of Research and Training for

Regional Development

Online at www.journals.cincader.org

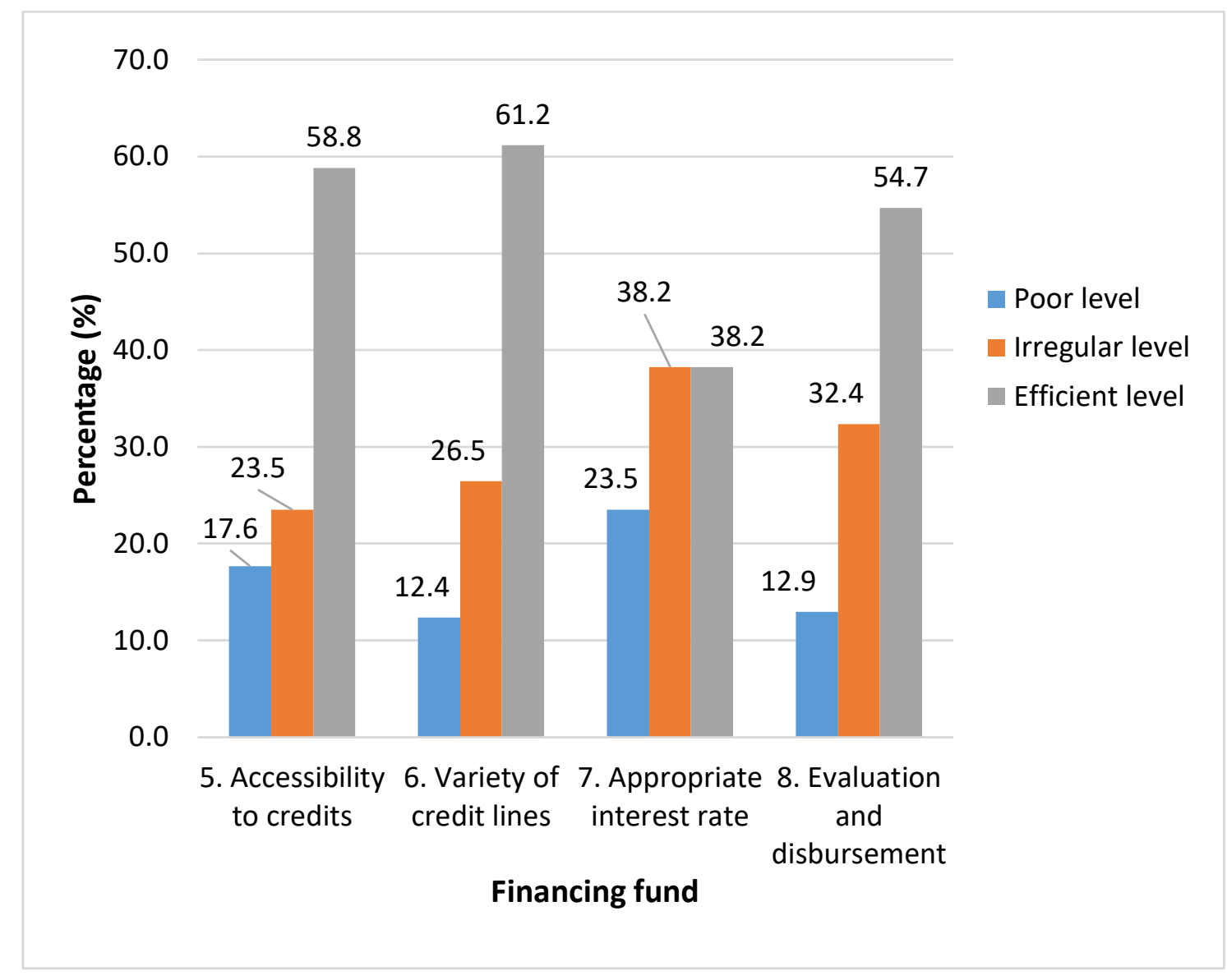

Figure 2. Financing fund

In the financing fund dimension, credit accessibility activities, variety of credit lines, interest rates, evaluation and disbursement were considered. Taking into account the accessibility to credit indicator, the following results were achieved: $58.8 \%$ of those surveyed stated that an efficient level was reached, $23.6 \%$ stated that it achieved an irregular level and also $17.6 \%$ said that it was reached a poor level. Taking into account the indicator variety of credit lines, the following results were achieved: $61.2 \%$ of those surveyed stated that an efficient level was reached, $25.6 \%$ expressed that it achieved an irregular level and also $12.4 \%$ said that it was reached at a poor level. Taking into account the interest rates indicator, the following results were achieved: $38.8 \%$ of those surveyed stated that an efficient level was reached, $38.2 \%$ stated that it achieved an irregular level and also $23.6 \%$ said that an poor level. Taking into account the evaluation and disbursement indicator, the following results were achieved: $54.7 \%$ of those surveyed stated that an efficient level was reached, $32.4 \%$ expressed that it achieved an irregular level and also $12.9 \%$ said that an poor level. 


\section{GMS \\ Journal of Global Management Sciences}

Vol. 3, $\mathrm{N}^{\circ}$ 2, 2020
Copyright (C) 2020, CINCADER.

ISSN 2663-0753

DOI: https://doi.org/10.32829/gms.v3i2.176

\section{CINCADER}

Centre of Research and Training for

Regional Development

Online at www.journals.cincader.org

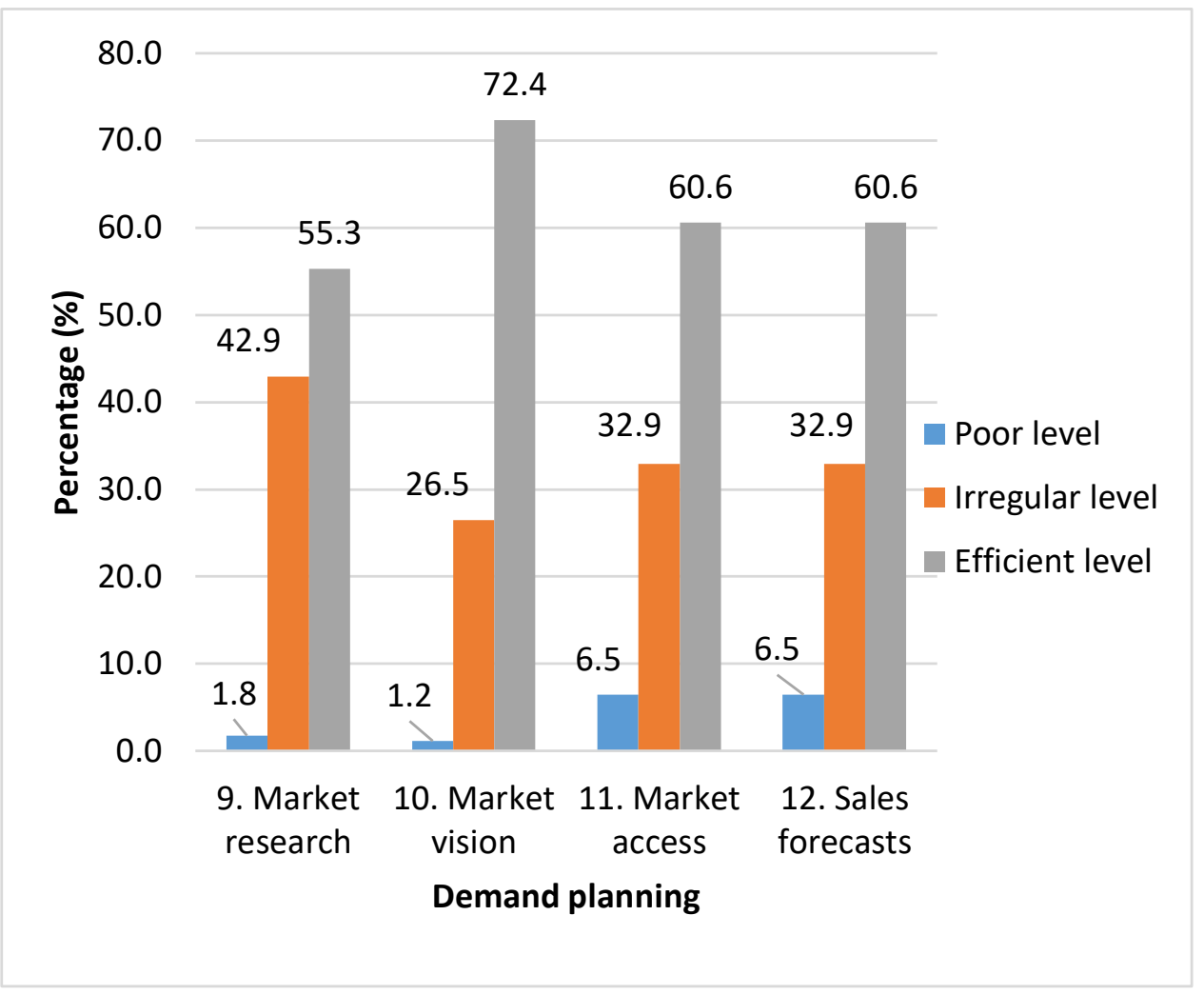

Figure 3. Demand planning

In the demand planning dimension. Market research activities, market vision, market access, sales forecasts were taken into consideration. Taking into account the market research indicator, the following results were achieved: $55.3 \%$ of those surveyed stated that an efficient level was reached, $42.9 \%$ expressed that it achieved an irregular level and also $1.8 \%$ said that an poor level. Taking into account the market vision indicator, the following results were achieved: $72.4 \%$ of those surveyed stated that an efficient level was reached, $26.5 \%$ stated that it achieved an irregular level and also $1.2 \%$ said that an poor level. Taking into account the market access indicator, the following results were achieved: $60.6 \%$ of those surveyed stated that an efficient level was reached, $32.9 \%$ stated that it achieved an irregular level and also $6.5 \%$ said that an poor level. Taking into account the forecast sales indicator, the following results were achieved: $60.6 \%$ of those surveyed stated that an efficient level was reached, $32.9 \%$ stated that it achieved an irregular level and also $6.5 \%$ said that an poor level.

\section{Conclusions}

- It is concluded that, in the dimension logistics distribution agents, it is appreciated that $82.40 \%$. An efficient level was achieved in relation to the attention of orders, and $17.60 \%$ established that it achieved an irregular level, this last aspect is considered as negative, because the orders are received based on the markets that are served and considering 


\section{GMS \\ Journal of Global Management Sciences}

Vol. 3, $\mathbf{N}^{\circ}$ 2, 2020
Copyright @ 2020 , CINCADER.

ISSN 2663-0753

DOI: https://doi.org/10.32829/gms.v3i2.176
A publication of

\section{CINCADER}

Centre of Research and Training for

Regional Development

Online at www.journals.cincader.org

the requirements of customers, which require that certain parameters be met in the packaging and presentation of the products. $64.10 \%$ stated that they achieved an efficient level, in relation to the handling of materials, $24.10 \%$ established that they achieved an irregular level and $11.80 \%$ said that they achieved an irregular level, these two aspects are considered negative, because the Customers have different requirements that must be met, such as the material used for packaging must be new (in the case of cardboard), clean and of a quality such as to avoid damage to the product and the use of materials is allowed. , in particular paper or stamps, bearing commercial specifications, provided they are printed or labeled with non-toxic ink or glues. $82.40 \%$ said that the logo was an efficient level, in relation to the use of the variety of packaging, $14.10 \%$ expressed that it achieved an irregular level and 3.5\% said that it achieved a deficient level, these two aspects are considered negative, because in the internal packaging paper is used to wrap the asparagus, which will be tied in bundles, this to avoid damage by humidity and in the external packaging the boxes are grouped in $11 \mathrm{lb}$ boxes to facilitate transport, handling, stowage and unitarization. $64.70 \%$ expressed that they reached an efficient level in the transport of products, $20.60 \%$ expressed that they achieved a deficient level, and $14.7 \%$ said that they achieved an irregular level, these two aspects are considered negative because they are takes into consideration that the transport of asparagus must be done at temperatures between 0 and $5^{\circ} \mathrm{C}$, depending on the duration of the trip and in the case of maritime transport, the optimum temperature is $2.2^{\circ} \mathrm{C}$, with a humidity of 90 to $95 \%$ and an Carbon dioxide level between 5 and $10 \%$.

- It is concluded that, in the financing fund dimension, it is appreciated that $58.80 \%$ state that an efficient level was achieved in accessibility to credits, $23.60 \%$ established that it achieved an irregular level, in addition that $17.60 \%$ achieved a deficient level These two aspects are considered negative, because agricultural activities are considered risky, due to the disintegration of the various commercial and financial circuits. $61.20 \%$ state that an efficient level was achieved in the variety of credit lines, $26.50 \%$ established that they achieved an irregular level, in addition that $12.40 \%$ achieved a deficient level, these two aspects are negative, because there are no credit lines accessible to small farmers, they know the technical-commercial management required to obtain quality agricultural products, but it is difficult to obtain the financing necessary for these technical standards to be met. $38.20 \%$ state that an efficient level was achieved in obtaining adequate interest rates, $38.20 \%$ established that they achieved an irregular level, in addition that $23.6 \%$ achieved a deficient level, these two aspects are negative because the interest rates they charge banks for granting a credit to companies to date are high, both in national and foreign currency. $54.70 \%$ state that an efficient level was achieved in the evaluation and disbursement of the credit, $32.40 \%$ established that they achieved an irregular level, and $12.90 \%$ achieved a deficient level, these two aspects are negative that are related to access to credits and the conditions that asparagus producers must meet in order to access credit.

- It is concluded that, in the demand planning dimension, it can be seen that $55.30 \%$ state that an efficient level was achieved in the development of market research, $42.90 \%$ established that it achieved an irregular level, in addition to that $1.80 \%$ achieved a deficient level, these two aspects are considered negative, because it is important to carry out studies to know the markets, customers, competition and the general environment where it has to compete. $72.40 \%$ state that an efficient level was achieved in the development of a market vision, $26.50 \%$ established that they achieved an irregular level, in addition that $1.20 \%$ achieved a deficient level, these two aspects are considered negative, because the producers They will have to take into consideration that the development of the business should take place taking into account the development of the value chain that allows them to demonstrate that the added value is important and 


\section{GMS

Vol. 3, $\mathrm{N}^{\circ}$ 2, 2020

Copyright @ 2020, CINCADER.

ISSN 2663-0753

DOI: https://doi.org/10.32829/gms.v3i2.176

the reason why this market vision is established. $60.60 \%$ state that an efficient level in market access was achieved, $32.90 \%$ established that it achieved an irregular level, in addition that $6.50 \%$ achieved a deficient level, these two aspects are considered negative, because the factors to be considered could be both external and political and economic situations with the target country, as well as internal, such as direct labor, or perhaps forces of nature that go beyond the power of man that limit this access. $60.60 \%$ state that an efficient level was achieved in the sales forecasts, $32.90 \%$ established that it achieved an irregular level, in addition that $6.50 \%$ achieved a deficient level, these two aspects are considered negative, because if it is not possible to determine product demand will not have a clear vision of how much to produce in type and quantity of products, so it is important to develop business models to make a projection of demand

\section{References}

Coronel, C. 2018. Factores de la competitividad en la asociación de productores agropecuarios Francisco Alvitez, Reque, para la mejora de la cadena productiva del espárrago. Tesis de Licenciatura, Universidad Católica Santo Toribio de Mogrovejo. Chiclayo, Peru.

Kaplinsky, R. 2000, Spreading the gains from globalization: What can be learned value chain analysis. Journal: Problems of Economic Transition, 47(2), 74-115, http://doi.org/10.1080/10611991.2004.11049908.

Lazzarini, S., Chaddad, F. y Cook, M. 2001, Integrating supply chain and network analyses: The study of net-chains. Wegeningen Academic publishers, 1(1), 7-22. http://doi.org//10.3920/JCNS2001.x002 .

Murillo, W. 2008. La investigación científica. http//www.monografias.com/ trabajos15/investcientífica/investcientífica.shtm

O'Brien, T., \& Díaz, A. 2004. Mejorando la competitividad y el acceso a los mercados de exportaciones agrícolas por medio del desarrollo y aplicación de normas de inocuidad y calidad: El ejemplo del espárrago peruano. http://infoagro.net/programas/Sanidad/pages/casos/capacitacion/esparrago_peru.pdf.

Pineda, Beatriz; De Alvarado, Eva Luz; De Canales, Francisca. 1994. Metodología de la investigación, manual para el desarrollo de personal de salud, Segunda edición. Organización Panamericana de la Salud. Washington.

Porter, Michael E. 1998, Clusters and the New Economics of Competition, Harvard Business Review, nov-dic., pp. 77-95.

Romero, D. La agroindustria en Veracruz ante la globalización. México: Arana Editores. 2001.

Zorrilla Arena, Santiago. 2007. Introducción a la metodología de la investigación. México Océano. 
Vol. 3, $\mathbf{N}^{\circ}$ 2, 2020

Copyright (c) 2020, CINCADER.

ISSN 2663-0753

DOI: https://doi.org/10.32829/gms.v3i2.176
Journal of Global

Management Sciences

Centre of Research and Training for Regional Development Online at www.journals.cincader.org

annexed

Questionnaire

\begin{tabular}{|l|l|l|l|}
\hline \multicolumn{1}{|c|}{ Dimension: Logistics distribution agents } & Poor level & $\begin{array}{c}\text { Irregular } \\
\text { level }\end{array}$ & $\begin{array}{c}\text { Efficient } \\
\text { level }\end{array}$ \\
\hline 1. Attention of orders & & & \\
\hline 2. Handling of materials & & & \\
\hline 3. Use of packaging's variety & & & \\
\hline 4. Transportation of products & & & \\
\hline \multicolumn{1}{|c|}{ Dimension: Financing fund } & & & \\
\hline 5. Accessibility to credits & & & \\
\hline 6. Variety of credit lines & & & \\
\hline 7. Appropriate interest rate & & & \\
\hline 8. Evaluation and disbursement & & & \\
\hline \multicolumn{1}{|c|}{ Dimension: Demand planning } & & & \\
\hline 9. Market research & & & \\
\hline 10. Market vision & & & \\
\hline 11. Market access & & & \\
\hline 12. Sales forecasts & & \\
\hline
\end{tabular}

